\title{
PREVALENCE OF INSOMNIA AND DEPRESSION IN PATIENTS WITH AGE-RELATED MACULAR DEGENERATION
}

\section{BEZSENNOŚĆ I ZACHOWANIA DEPRESYJNE U PACJENTÓW ZE ZWYRODNIENIEM PLAMKI ŻÓŁTEJ ZWIĄZANYM Z WIEKIEM}

\author{
Elżbieta Nowak $^{1(\mathrm{~A}, \mathrm{~B}, \mathrm{C}, \mathrm{D}, \mathrm{E})}$, Aleksandra Kulik ${ }^{2(\mathrm{D}, \mathrm{E})}$, Justyna Wróbel ${ }^{2(\mathrm{~B}, \mathrm{D})}$, Grzegorz Nowak $^{3(\mathrm{C}, \mathrm{F})}$, \\ Damian Nowak $^{4(C, F)}$, Wojciech Roczniak ${ }^{2(E, F)}$, Jadwiga Jośko-Ochojska ${ }^{1(A, E)}$
}

\author{
${ }^{1}$ Department of Environmental Medicine and Epidemiology, School of Medicine with the Division of Dentistry \\ in Zabrze, Medical University of Silesia, Katowice, Poland \\ ${ }^{2}$ Department of Toxicology and Health Protection, School of Public Health in Bytom, Medical University of Silesia, \\ Katowice, Poland \\ ${ }^{3}$ Department of Hygiene, Faculty of Medicine, Wroclaw Medical University, Poland \\ ${ }^{4}$ Department of Physiology, School of Medicine with the Division of Dentistry in Zabrze, Medical University of Silesia, \\ Katowice, Poland
}

Authors' contribution

Wkład autorów:

A. Study design/planning zaplanowanie badań B. Data collection/entry zebranie danych C. Data analysis/statistics dane - analiza i statystyki D. Data interpretation interpretacja danych E. Preparation of manuscript przygotowanie artykułu F. Literature analysis/search wyszukiwanie $i$ analiza literatury G. Funds collection zebranie funduszy
Tables: 4

Figures: 2

References: 30

Submitted: 2017 March 03

Accepted: 2017 Apr 04
Summary

Background. Age Related Macular Degeneration (AMD) affecting the organ of vision, impairs central vision. The study objective was (1) to define the prevalence of sleep disorders and depressive symptoms in patients with AMD, (2) to assess the relationship of depressive symptoms and insomnia with chosen demographic data, (3) to assess a potential correlation of the exacerbating vision quality with depressive symptoms and sleep disorders. Material and methods. The study involved 105 patients, women and men aged 45-88. Patients were asked to complete an original questionnaire subjected to validation, the Beck Depression Inventory and the Athens's Insomnia Scale. Results. The results were analysed statistically, showing that $71 \%$ of the respondents had insomnia and $70 \%$ suffered from depression. The patients' age, time from the diagnosis, marital and occupational status were not found to be related to depression or sleep disorders. Type of education, financial status and family support were significantly correlated with the prevalence of depression and sleep disorders. No correlation was observed between the exacerbation of vision disorders and enhanced depressive symptoms and insomnia. However, such correlation was noted with subjective stress reactions. Conclusions. Since patients with AMD are at a greater risk of sleep disorders and depression they should remain under professional care of a multidisciplinary team, including an ophthalmologist, a family doctor, a psychiatrist and a psychologist.

Keywords: age related macular degeneration, AMD, insomnia, depression

\section{Streszczenie}

Wprowadzenie. Zwyrodnienie plamki żółtej związane z wiekiem (AMD, Age Related Macular Degeneration) jest schorzeniem narządu wzroku, które istotnie upośledza widzenie centralne. Celem badania było: (1) określenie częstości występowania zaburzeń snu oraz objawów depresyjnych u pacjentów z AMD, (2) zbadanie zależności pomiędzy objawami depresyjnymi i bezsennością a wybranymi danymi demograficznymi, (3) oszacowanie korelacji pomiędzy pogarszaniem się jakości widzenia a objawami depresyjnymi i zaburzeniami snu. Materiał i metody. W badaniu wzięło udział 105 pacjentów, kobiet i mężczyzn w wieku od 45 do 88 lat. Pacjenci poproszeni zostali o wypełnienie autorskiej zwalidowanej ankiety, skali depresji Becka oraz Atteńskiej Skali Bezsenności. Wyniki. Stwierdzono, że na bezsenność cierpi $71 \%$ respondentów, natomiast objawy depresji występują u 70\% badanych. Wiek badanych, czas od postawienia diagnozy, stan cywilny oraz status zawodowy nie były związane z zaburzeniami depresyjnymi oraz snu. Rodzaj wykształcania, sytuacja materialna oraz wsparcie ze strony najbliższych (rodziny) były istotnie skorelowane z częstością występowania zaburzeń depresyjnych oraz snu. Nie stwierdzono korelacji pomiędzy narastaniem zaburzeń jakości widzenia a nasileniem objawów depresyjnych i bezsennościa, natomiast taka zależność zaobserwowano w odniesieniu do subiektywnej reakcji stresowej. Wnioski. Chorzy na AMD są grupą pacjentów podwyższonego ryzyka wystąpienia zaburzeń snu oraz rozwoju depresji i w związku z tym powinni zostać objęci opieką wielodyscyplinarnego zespołu, w którym oprócz lekarza okulisty powinien znaleźć się lekarz rodzinny, psychiatra oraz psycholog.

Słowa kluczowe: zwyrodnienie plamki żółtej związane z wiekiem, AMD, bezsenność, depresja

Nowak E, Kulik A, Wróbel J, Nowak G, Nowak D, Roczniak W, et al. Prevalence of insomnia and depression in patients with age-related macular degeneration. Health Prob Civil. 2018; 12(4): 255-264. https://doi.org/10.5114/hpc.2018.76518

Address for correspondence / Adres korespondencyjny: Aleksandra Kulik, Department of Toxicology and Health Protection, School of Public Health in Bytom Medical University of Silesia, Katowice, Piekarska 18, 41-902 Bytom, Poland, e-mail: akulik@sum.edu.pl, phone: +48322755995

Copyright: (C) Pope John Paul II State School of Higher Education in Biała Podlaska, Elżbieta Nowak, Aleksandra Kulik, Justyna Wróbel, Grzegorz Nowak, Damian Nowak, Wojciech Roczniak, Jadwiga Jośko-Ochojska. This is an Open Access journal, all articles are distributed under the terms of the Creative Commons Attribution-NonCommercial-ShareAlike 4.0 International (CC BY-NC-SA 4.0) License (http://creativecommons.org/licenses/by-nc-sa/4.0/), allowing third parties to copy and redistribute the material in any medium or format and to remix, transform, and build upon the material, provided the original work is properly cited and states its license. 


\section{Introduction}

The process of ageing is associated with a number of various organic changes occurring in all cells, tissues, organs and systems of the body, including the organ of vision and the central nervous system (CNS). The involution processes of the CNS may lead to specific disorders, commonly treated as a natural and predictable aspect of ageing. This refers to circadian rhythm disturbances, i.e. sleep/wakefulness and mood disorders that manifest themselves primarily in the form of depression [1].

Epidemiological data indicate that at least 3\% of the population suffer from depression. This ratio seems to be higher in European countries (4\%). The estimates taking into account the so-called masked depression reach $10 \%$ and only $20 \%$ of patients benefit from specialised medical care. Clinicians believe that depression is much more frequent in the elderly. However, only a few studies have confirmed the existence of such relationship [2].

Also daily clinical practice shows that patients with depression (major depression according to DSM) represent up to $50 \%$ of elderly patients treated in psychiatric wards; $40 \%$ of patients in daily psychiatric wards and equally significant percentage of patients in residents' homes (30-40\%) or those treated by family doctors $(15-30 \%)$ [3]. These data appear to be inconsistent with the results of a population study, suggesting that the prevalence of major depression in the elderly does not differ significantly from that observed among younger people $(4.6-9.3 \%)[4]$.

One of the elements that negatively affect mental health is vision deterioration and the resulting decrease in the quality of life. According to the WHO reports, vision impairment concerns about $20 \%$ of the elderly on a global scale [5] and, importantly, it is steadily increasing. Most of the previous studies addressing the problem of depressive disorders and their association with age-related vision disorders have focused mainly on diseases that can be successfully treated (e.g. glaucoma, cataracts). No attempt, however, has been made to diagnose eye diseases which caused vision impairment $[6,7]$.

Loss of central vision considerably interferes with daily functioning, e.g. reading, recognising faces, performing activities that require good near vision, which significantly affects the quality of life, independence, self-sufficiency and widely understood mood [8]. In contrast, glaucoma is often characterised by an insidious onset of retinal fibre nerve damage responsible for peripheral vision, so that its impact on daily activities may be visible only in very advanced stages of the disease. Furthermore, in contrast to cataract and glaucoma, current treatment options for AMD are limited, and the methods leading to slowing down the disease progression are unsatisfactory [9].

AMD is a disease associated with enhanced ageing of the macular region, which is characterised by (1) geographic atrophy of pigment epithelium (2), retinal pigment epithelium detachment (3), subretinal or choroidal neovascularisation under pigment epithelium (4), and effusions and hemorrhages with fibrous and glial scar formation [10]. AMD is the leading cause of irreversible vision loss (blindness) in people over the age of 50 in developed countries. Numerous statistical data show that the disease affects approximately $10 \%$ of the population aged $65-74$ years, and $30 \%$ - over 75 years of age [11].

The pathogenesis of AMD is complex and not fully elucidated. The processes involved in AMD include (1) lipofuscinogenesis (in pigment epithelial cells) and (2) drusogenesis (formation of drusen between the layer of the retinal pigment epithelium and Bruch's membrane). Two primary forms of AMD are distinguished, i.e. atrophic (dry) and exudative (wet). Each of the two is originally a disorder of retinal blood supply. The dry form of AMD is much more common (about 85\%), and so far no effective treatment has been found for this group of patients $[10,12]$.

Despite intensive research into the pathogenesis, course and treatment of AMD there is still a lot of confusion and controversy. Thus, patients diagnosed with AMD have no choice but to accept the quality of life associated with the disease accompanied by progressive blindness. Up to date, most studies on AMD have focused on the effectiveness of treatment and other factors influencing the progression of vision loss and deterioration of visual acuity. Some studies, however, have pointed to the need for thorough evaluation of the quality of life of patients with AMD since visual acuity alone may not provide an adequate basis for the assessment.

Since AMD can manifest itself by the impairment of central vision, deterioration of contrast sensitivity, the presence of metamorphopsia, micropsia, macropsia and others, it can significantly impair the quality of life (difficulty reading documents, the use of watch, recognizing people's faces, etc.) and at the same time be a dominant stressogenic factor for people affected by AMD. However, few studies concerning these issues provide ambiguous data.

Therefore, the aim of the current research was to: (1) assess the severity of insomnia and depressive symptoms in patients with previously diagnosed and clinically confirmed macular degeneration associated with age, (2) estimate possible correlation of vision deterioration with depressive symptoms and sleep disorders, (3) examine the relationship between depressive symptoms and insomnia, and selected demographic data. 


\section{Material and methods}

The study involved 105 patients with AMD, both sexes, aged from 45 to 88 years, who reported at the Ophthalmic Outpatient Clinic for a routine check-up. They had been previously diagnosed with age-related macular degeneration, which was clinically confirmed. After ophthalmic examination, patients were asked to complete a validated questionnaire prepared by the researchers, the Beck Depression Inventory (Beck) and the Athens Insomnia Scale (ATE).

The survey contained a number of basic questions concerning gender, age, place of residence, etc., and referring to the disease course, medical treatment, subjective evaluation of vision (distorted vision, a spot in front of the eye) and subjective assessment of the severity of stress response due to impaired vision.

The ATE is the scale in which the examined person chooses answers to 8 questions assessing the following components: falling asleep, waking up during the night, waking up in the morning, total sleep time, sleep quality, mood next day, mental and physical efficiency the next day and sleepiness during the day. Each response is assigned a point value from 0 (no difficulty) to 3 (severe difficulty). The total score ranges from 0 to 24 points. The higher the result, the more inferior the quality of sleep. The assessment relates to the quality of sleep during the past week [13].

The BECK scale is one of the most commonly used methods to measure the severity of depression. It consists of 21 points evaluating the intensity of symptoms ranging from 0 to 3 . Interpretation of the results is based on the following score: 0 to 9 points: no symptoms of depression; 10 to 19: light depression; 20 to 25: mild depression; above 25 points: severe depression [14].

Qualifying patients to the survey was based on the following inclusion criteria: (a) clinically recognised AMD, (b) age from 45 to 90 years, and (c) patient's consent to take part in the study. The exclusion criteria were: (a) other ophthalmic diseases that accompany AMD impairing visual acuity (e.g.glaucoma, diabetic retinopathy), (b) a very advanced form of AMD where visual acuity prevents accurate completion of the survey, and (c) patient's refusal to take part in the study.

Since 12 questionnaires were filled incorrectly (out of 117), only 105 questionnaires were included in further analysis. Selected parameters from the patient's documentation, such as the maximum obtained distance and near visual acuity, and type of AMD treatment were also evaluated.

The assessment of near vision according to Snellen charts (SN) adopted the following distribution: D 0.50 0.75 - very good; D 1.00 - 1.25 - good; D 1.50 - 2.00 - average; D 2.25 - 3.00 - poor; D (fails to read optotypes) - very poor (for the purpose of statistical analysis the number 4.00 was assumed ). To assess distance vision according to Snellen charts (V) the following distribution was adopted: 0.8-1.0 D - very good; D 0.5-0.7 - good; 0.2-0.4 D average; D 0.02-0.1-poor; hand movement in front of the eye - very poor.

The study was approved by the Bioethics Committee of the SUM, 21 June 2011. No: CDF / 0022 / KB1 / 74 / I / 11.

Statistical analysis was performed using STATISTICA 8.0 PL and MS Excel 2007. Values calculated for quantitative variables were expressed as the arithmetic mean, standard deviation (SD) or percentage, and for qualitative variables in percentages. The statistical analysis was performed with nonparametric Mann-UWhitney and Kruskal-Wallis tests. The Spearman test was used to evaluate correlations. P value $<0.05$ was estimated as statistically significant.

\section{Results}

The mean age of the surveyed patients was 69.9 years (median 72 years) and the average time from the diagnosis was 3.9 years (median 3 years). There were $10 \%$ of patients over 80 years of age, $47 \%$ between 71 - 80 years of age, $27 \%$ aged $61-70$ years, $15 \%$ aged $60-50$ years and $2 \%$ below the age of 50 . Women accounted for $66 \%$ of the respondents, $34 \%$ were men. In the study group, $65 \%$ of the respondents were married and $35 \%-$ single. Higher education was declared by $13 \%$ of the respondents, secondary by $54 \%$ and primary by $32 \%$. As many as $88 \%$ of the respondents were professionally inactive, the remaining $10 \%$ performed physical work and $2 \%$ mental work. In $43 \%$ of the respondents financial status was good, in $52 \%$ - average and in $5 \%$ - bad. Family support was described as good by $38 \%$ of the respondents, average by $54 \%$, and none by $8 \%$ (Table 1 ). 
Table 1. Selected sociodemographic data

\begin{tabular}{|c|c|}
\hline Data & $\begin{array}{c}\text { Values } \\
(\%)\end{array}$ \\
\hline \multicolumn{2}{|c|}{ Age } \\
\hline$<50$ & 2 \\
\hline $50-60$ & 15 \\
\hline $61-70$ & 27 \\
\hline $71-80$ & 47 \\
\hline$>80$ & 10 \\
\hline \multicolumn{2}{|c|}{ Gender } \\
\hline Men & 34 \\
\hline Women & 66 \\
\hline \multicolumn{2}{|c|}{ Marital status } \\
\hline Married & 65 \\
\hline Single & 35 \\
\hline \multicolumn{2}{|c|}{ Education } \\
\hline Primary & 32 \\
\hline Secondary & 54 \\
\hline Higher & 13 \\
\hline \multicolumn{2}{|c|}{ Occupational status } \\
\hline Mental work & 2 \\
\hline Physical work & 10 \\
\hline Non-working & 88 \\
\hline \multicolumn{2}{|c|}{ Financial status } \\
\hline Good & 43 \\
\hline Average & 52 \\
\hline Bad & 5 \\
\hline \multicolumn{2}{|c|}{ Family support } \\
\hline Good & 38 \\
\hline Average & 54 \\
\hline Lacking & 8 \\
\hline
\end{tabular}

The largest group of respondents were those diagnosed within 3 years before the survey (58\%), 22\% 4-6 years, 11\% 7-9 years, the remaining patients over 10 years. Visual disturbances known as "image distortion" or "spot" in the central vision were declared by $68 \%$ of the respondents. In the subjective assessment of the severity of "stress response" in patients with blurred vision associated with AMD and thus difficulties in everyday functioning (e.g. difficulty in reading documents, using the watch, recognition of signs, faces, etc.) as many as $74 \%$ of patients experienced stress-related vision problems $(38 \%$ answered "definitely yes", $36 \%$ "rather yes", 21\% "rather not" and 5\% "not"). Thirty-two per cent of the respondents were treated with monoclonal antibodies and $68 \%$ with vitamin preparations. Laser therapy was not used at all. Changes in dietary habits after the diagnosis of AMD were declared only by $34 \%$ of the patients, $18 \%$ admitted cigarette smoking at present and $30 \%$ smoking in the past (Table 2).

Table 2. Selected ophthalmic parameters and other disease-related data

\begin{tabular}{|c|c|}
\hline Data & \multicolumn{1}{|c|}{$\begin{array}{c}\text { Values } \\
\text { (\%) }\end{array}$} \\
\hline \multicolumn{2}{|c|}{ Time from the diagnosis (years) } \\
\hline$<3$ & 58 \\
\hline $4-6$ & 22 \\
\hline $7-9$ & 11 \\
\hline$>9$ & 9 \\
\hline \multicolumn{2}{|c|}{ Visual disturbances distorted image or spot } \\
\hline Present & \multicolumn{2}{|c|}{32} \\
\hline Absent & \\
\hline
\end{tabular}




\begin{tabular}{|c|c|}
\hline \multicolumn{2}{|c|}{ Subjective assessment of stress response severity } \\
\hline Definitely YES & 38 \\
\hline Rather YES & 36 \\
\hline Rather NOT & 21 \\
\hline Definitely NOT & 5 \\
\hline \multicolumn{2}{|c|}{ Type of treatment } \\
\hline Monoclonal antibodies & 32 \\
\hline Vitamin preparations & 68 \\
\hline Laser therapy & 0 \\
\hline \multicolumn{2}{|c|}{ Changes in dietary habits } \\
\hline Yes & 34 \\
\hline No & 66 \\
\hline \multicolumn{2}{|c|}{ Smoking } \\
\hline Still smoke & 18 \\
\hline Past habit & 30 \\
\hline
\end{tabular}

Insomnia was diagnosed in $71 \%$ of the respondents (6 or more points in the Athens Insomnia Scale) (Fig. 1).

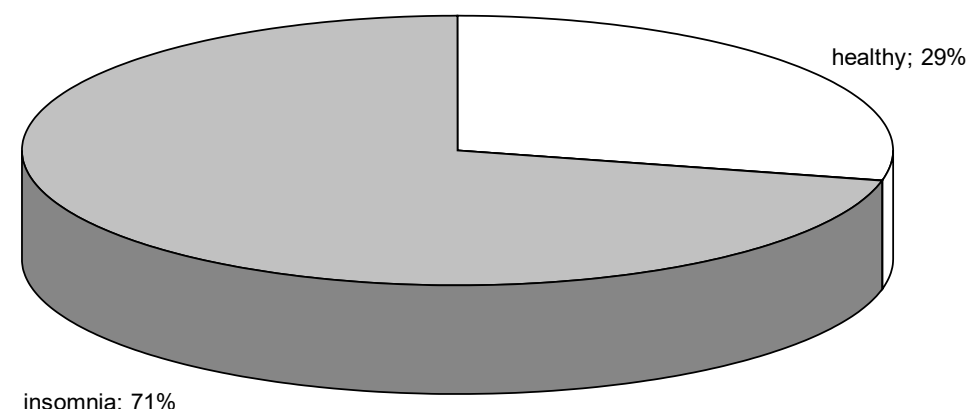

The Athens's Insominia Scale

Figure 1. The prevalence of insomnia in patients with AMD

Depressive disorders were found in $70 \%$ of the respondents, including mild depression symptoms in $39 \%$, moderately severe in $16 \%$ and very severe in $15 \%$. No symptoms of depression were found in $30 \%$ of the respondents (Fig. 2).

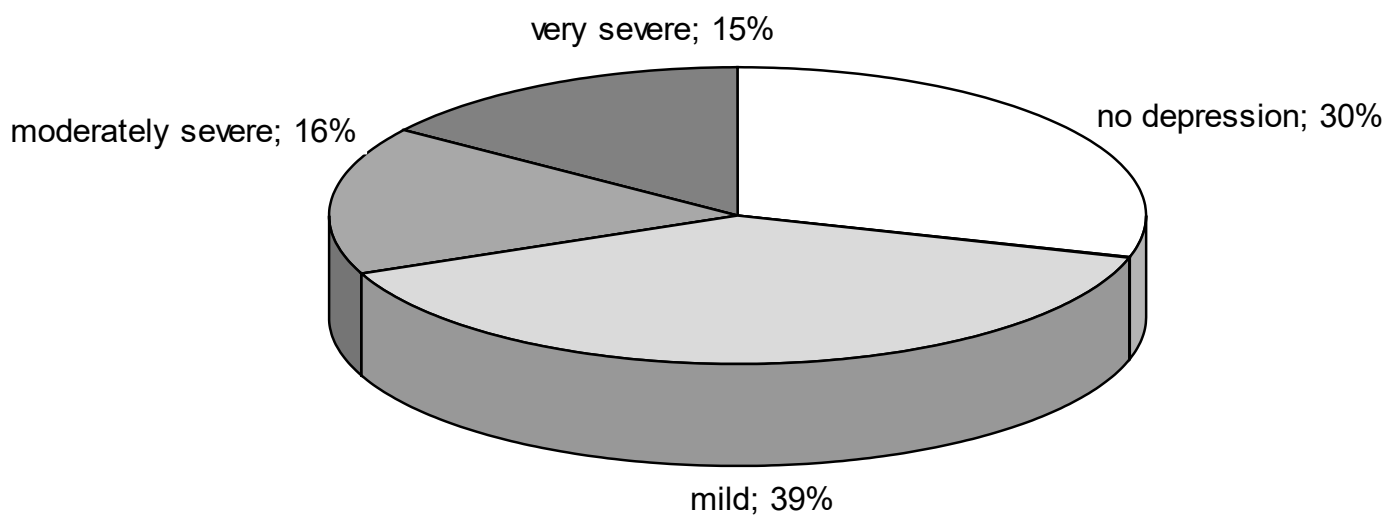

The Beck Depression Inventory

Figure 2. The prevalence of depression in patients with AMD

Comorbid diseases, such as hypertension, ischemic myocardial disease, arrhythmias were diagnosed in $72 \%$, $29 \%$ and $12 \%$ of the study subjects, respectively. Among other frequently mentioned diseases was diabetes (14\%). None of the respondents mentioned taking antidepressants or antipsychotic drugs (data not shown in a tabular form). 
Among the surveyed patients, $73 \%$ showed a very good and $27 \%$ a good visual acuity for near vision (in the eye with better vision). In the eye with worse vision, $35 \%$ of the patients showed a very good visual acuity for near vision, $23 \%$ good, $11 \%$ average, $14 \%$ poor and $16 \%$ very poor. A very good visual acuity for distant vision was found in $56 \%$, good in $31 \%$, average in $11 \%$ and poor in $1 \%$ (in the eye with better vision). In the eye with worse vision, $22 \%$ of the patients had a very good visual acuity for distant vision, $23 \%$ good, $22 \%$ average, $25 \%$ poor and $9 \%$ very poor (Table 3 ).

Table 3. Vision quality in patients with AMD

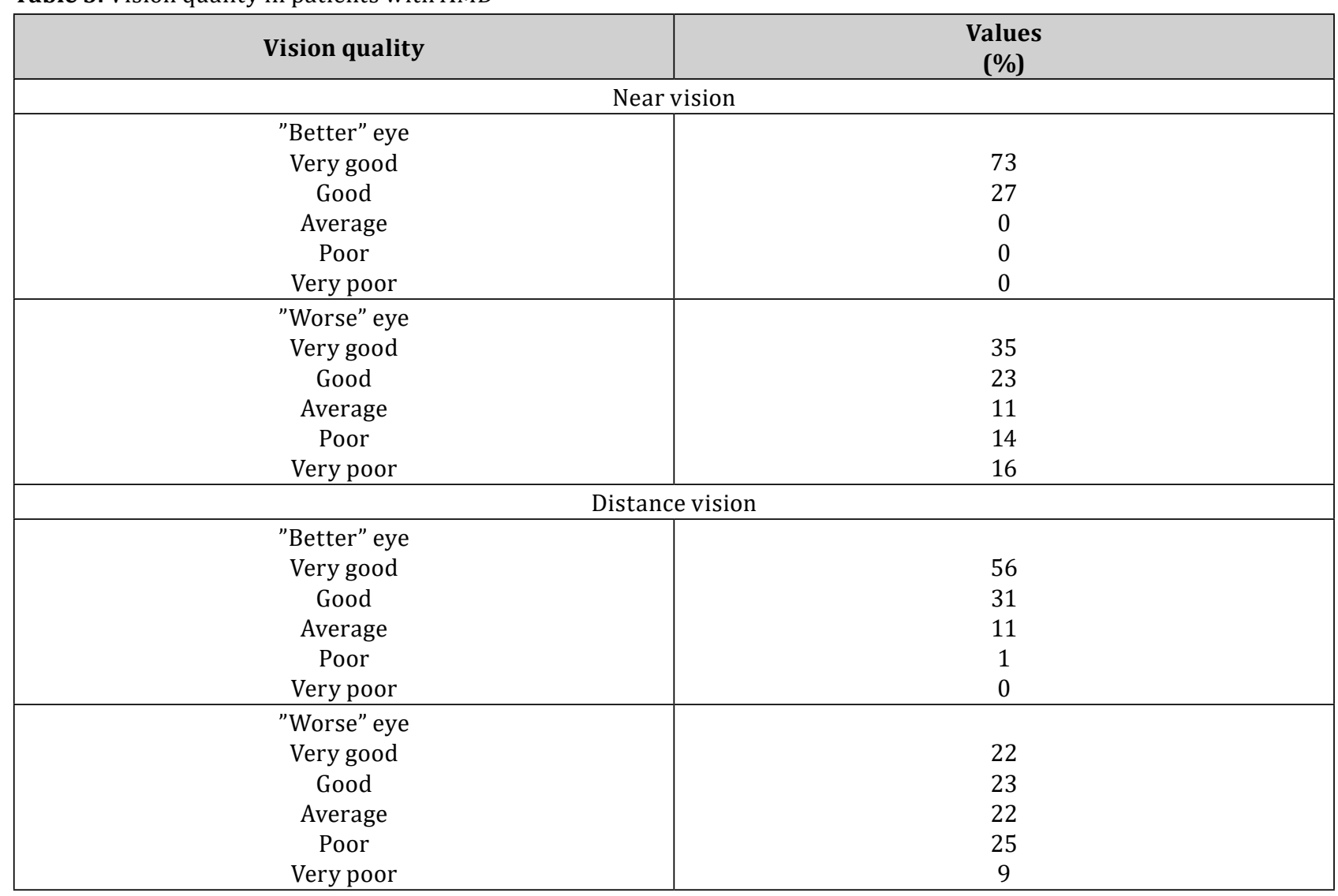

In the study population of AMD patients, women were significantly more likely to suffer from insomnia than men (72\% and 28\%, respectively), and were also significantly more likely to have depressive symptoms. There was no correlation between the type of education and the results of ATE, while less educated patients were significantly more likely to show depressive symptoms. Moreover, patients with worse financial status and with no family support significantly more frequently suffered from insomnia and depression.

Furthermore, a moderately strong correlation was revealed between ATE results and Beck Depression Inventory data (Spearman $\mathrm{R}=0.6317, \mathrm{p}<0.05$ ). It was shown that the severity of "stress response" increased with a deterioration of near and distance vision, both for the eye with better and worse vision. It was also found that the presence of visual disturbances in the form of a distorted image or spot deteriorated the quality of near and distance vision (for the eye with better and worse vision) (Table 4).

Table 4. Statistical analysis of chosen parameters

\begin{tabular}{|c|c|c|c|}
\hline Analysed parameters & N valid & $\begin{array}{c}\text { ATE } \\
\text { (p value) }\end{array}$ & $\begin{array}{c}\text { BECK } \\
\text { (p value) }\end{array}$ \\
\hline Gender & 105 & $<\mathbf{0 . 0 5}$ & $<\mathbf{0 5}$ \\
\hline Age & 105 & 0.090 & 0.078 \\
\hline Education & 105 & 0.075 & $<\mathbf{0 . 0 5}$ \\
\hline Occupational status & 105 & 0.639 & 0.606 \\
\hline Marital status & 105 & 0.477 & 0.719 \\
\hline Financial status & 105 & $<\mathbf{0 . 0 5}$ & $<\mathbf{0 . 0 5}$ \\
\hline
\end{tabular}




\begin{tabular}{|c|c|c|c|}
\hline Family support & 105 & $<0.05$ & $<0.05$ \\
\hline Time from AMD diagnosis (years) & 105 & 0.565 & 0.3847 \\
\hline Assessment of stress response & 105 & 0.996 & 0.515 \\
\hline Near vision - better eye & 105 & 0.625 & 0.505 \\
\hline Near vision - worse eye & 105 & 0.057 & 0.090 \\
\hline Distance vision - better eye & 105 & 0.231 & 0.715 \\
\hline Distance vision - worse eye & 105 & 0.934 & 0.394 \\
\hline ATE & 105 & - & $<0.05$ \\
\hline Analysed parameters & N valid & $\begin{array}{c}\text { Assessment of stress } \\
\text { response }\end{array}$ & $\begin{array}{c}\begin{array}{c}\text { Distorted vision or } \\
\text { spot }\end{array} \\
\end{array}$ \\
\hline Near vision - better eye & 105 & $<0.05$ & $<0.05$ \\
\hline Near vision - worse eye & 105 & $<0.05$ & $<0.05$ \\
\hline Distance vision - better eye & 105 & $<0.05$ & $<0.05$ \\
\hline Distance vision - worse eye & 105 & $<0.05$ & $<0.05$ \\
\hline
\end{tabular}

\section{Discussion}

Among many factors that can negatively affect person's mental health, vision deterioration and in consequence decreased life quality are mentioned. AMD is an eye disorder caused by retinal damage in the macula which significantly impairs central vision and has a poor prognosis. Relatively early patients complain of difficulty reading documents, seeing the time on the watch, recognising faces and signs, etc. All this interferes with daily functioning, hinders independence and self-sufficiency, and is also a strong stressogenic factor for the people affected.

There are no literature data on sleep disorders in patients with AMD. However, insomnia can be found in as many as 50\% [15] to 83\% [16] of respondents with severe deterioration of vision (10\% of vision in one eye) or entirely blind. In our study, $71 \%$ of AMD patients had insomnia.

It should be remembered that sleep disorders are very specific of depression and by some authors considered a very strong biomarker of the disease. Complaints of sleeplessness are common in people over the age of 65 , who report this problem as a major one to their family doctors [17]. It is easier for patients to inform about sleep disorders and insomnia than dejection, sadness or depression. They treat insomnia as a somatic disease, like abdominal or chest pain. It is easier to describe it in a parametric way in contrast to depression Although depression usually starts with insomnia, patients may complain of sleeplessness directly before the onset of lower mood or at different times [18]. The results of the current study confirmed a correlation between sleep disorders and depressive symptoms in patients with AMD.

Using the Beck's Depression Scale, we found symptoms of mild depression in 39\%, moderate to severe in $16 \%$, and very severe in $15 \%$ of the respondents. In total, $70 \%$ of the study population with AMD showed symptoms typical of depression, which seems to be very disturbing. Our study results appear to be twice as high as the reported world data. Brody et al. [19] using the Geriatric Depression Scale found that 32.5\% of AMD patients (mean age 80 years) met the criteria for depression and the proportion was twice as much as for the age-matched population without ophthalmic diseases.

Also, Rovner et al. [20] presented similar data (33\%), and Qian et al. [21] found depression in 39.3\% of patients with inflammatory diseases of the eye. These results seem alarming, especially if we consider that they are similar or even higher than those reported in coronary artery disease (18\%), cerebral infarction (26\%) and cancer $(15-29 \%)$.

It is worth noting that the prevalence of depression in the elderly population with no health complaints and somatic or mental diseases ranges from $8 \%$ to $16 \%[22,23]$. The discrepancy in the results between the current study and the investigations cited above can be explained by differences in research methodology, i.e. using different scales to estimate the symptoms of depression and adopting the cut-off point of 9 for healthy people in the Beck's scale, and not 13 as reported elsewhere [21]. The discrepancies may also be explained by socioeconomic variables, hindered access to health care and differences in the involvement of state institutions in helping AMD patients in Poland and the world. This hypothesis has been supported by the results of studies conducted on the Polish population. Weterle and Sołtysiak [24] analysing the prevalence and estimating the number of undiagnosed cases of depressive disorders in patients over 65 who were hospitalised in the geriatric ward, found depressive symptoms in $41.7 \%$ of patients.

In the current study, the majority of patients with depressive symptoms were women - 80.9\% (52\% of all women surveyed), as compared to $22.6 \%$ of male respondents. On the other hand, Kowalska et al. [25] who 
assessed patients (mean age 77.7 years) rehabilitated in the Care and Nursing Home found $71.6 \%$ of patients with cognitive impairment, $16.5 \%$ with mild cognitive impairment without features of dementia and only $11.8 \%$ with good results. In contrast, depressive symptoms on admission to the ward were noted in $65.2 \%$ of patients (evaluation using the geriatric depression scale) and depressed mood was observed in nearly $70 \%$ of patients hospitalised due to orthopedic injuries and stroke. Thus, the results better reflect the diversity of the Polish population of patients and are consistent with our findings. It should be noted, however, that the figures quoted above relate to hospitalised patients. Research conducted among outpatients has revealed a much lower figure (about 41\%) [25], whereas data for the general population are even lower, indicating that approximately 15-20\% of people over the age of 65 show depressive symptoms [3].

As previously stated, in the currently analysed group of patients with AMD 70\% showed symptoms typical of depression, but at the same time, no correlation was noted of vision deterioration with depression severity and sleep disorders. Also, Chojnacka [26] found that patients with cataract (approximately 90\% of the study patients) or other ophthalmic diseases (the remaining 10\% - glaucoma or AMD) showed no relationship between the decrease in visual acuity and the presence and severity of depressive symptoms. Moreover, she failed to find a correlation between depressive symptoms and additional somatic diseases (and their number), but showed a relationship between the quality of life and depressive symptoms (the worse the quality of life of patients the more significant the severity of depression). The above may be difficult to explain, since permanent deterioration of visual acuity usually leads to significantly reduced independence, difficulties in performing daily activities, and problems with human relations due to fear of falling down or not recognising friends' faces.

In the current study, no relationship was also found between the age of patients, their occupational status, marital status, time from AMD diagnosis and the presence of depressive symptoms and insomnia. Lack of such correlations between demographic data and such parameters as anxiety, depression, etc., in people with impaired vision, has also been confirmed by other researchers [27].

At the same time, we found that depressive disorders and insomnia are more common in women than in men, which is consistent with the works of other authors. The rate of at least one depression episode in women is $7-21 \%$ as compared to men $(2.6-13 \%)$.

It is worth noting that these gender differences are fairly cohesive all over the world. The pathomechanism of mental disorders in women is a combination of a number of factors, including genetic, hormonal (hormones involved in the regulation of the menstrual cycle) and psychosocial associated with functioning in the family and at work. Some of them do not refer to men, which may partially explain the differences observed. The results of the current study also indicate that education, economic status and family support among AMD patients correlates with the severity and prevalence of depressive disorders and insomnia.

Less educated patients, with reduced financial status, deprived of family support often exhibit depression symptoms and sleep problems. The interpretation of these results should take into consideration that the average age of the study population was 70 years and thus, all the study participants were elderly. There are many indications that the risk of depression and insomnia in this population is significantly associated with the specificity of this life period. Depressive disorders in the elderly can be subject to many psychological, social and biological (organic) factors. In the elderly years, the major role is attributed to the latter, but equally important are the psychological and social aspects, and their mutual relations are usually difficult to identify, as they can coexist and overlap.

Social factors may include difficult financial conditions, loneliness and in consequence social isolation, as well as negative social attitudes towards the ageing process. Among the most important psychological factors, there are the so-called "losses", e.g. the loss of beloved and friends, the socio-occupational status, health, private property and the associated feeling of inaction and helplessness. Importantly, the awareness that these losses are usually irreversible further intensifies the severity of this phenomenon [24]. Other researchers have also confirmed that worse financial situation, lack of family support and poor education are factors that favour the occurrence of depression and insomnia [28].

As mentioned earlier, substantial vision deterioration in patients with AMD can be the cause of disability. Williams et al. [27] conducted a survey assessing the quality of life in 86 AMD patients with a very poor visual acuity. He showed that the quality of life of AMD patients was significantly worse, not only compared to the general population, but also to patients with other serious diseases, such as chronic obstructive pulmonary disease or AIDS. He also showed that compared to the overall population (subjects without visual impairment), patients with AMD were 8 times more likely to experience problems with doing the shopping, 13 times more prone to problems with managing their finances, 4 times more often having problems with preparing food, 9 times more likely to have problems with minor housework, 12 times more prone to problems associated with using the phone. These difficulties were not without an effect on mental wellbeing, as the cited authors who 
used the Profile of Mood States (POMS) correlated the emotional state of the study patients with other scales evaluating other parameters (quality of life, self-assessment of health status, physical activity, etc.).

The cited authors have revealed that AMD patients experience anxiety, tension, anger and annoyance that increase with vision deterioration. The emotional state of this group of patients is similar to that observed among patients with malignant melanoma, AIDS and those waiting for bone marrow transplantation. Their results partly confirm the observations made in the current study. The subjective assessment of the severity of "stress response" to blurred vision associated with AMD and thus difficulties in everyday functioning (e.g. reading documents, using a watch, recognising people's faces, etc.) showed that $74 \%$ of the patients experience stress related to vision problems (38\% of respondents answered "definitely yes", 36\% "rather yes", $21 \%$ "rather not" and 5\% "definitely not").

Moreover, a relationship was found between the presence of a "distorted image or spot" and the quality of near and distance vision and between the quality of near and distance vision and the intensity of stress response, i.e. the subjective feeling of discomfort and stress increased with vision deterioration in patients with AMD.

It is also worth mentioning that most of the patients surveyed (66\%) declared no change in their dietary habits despite being diagnosed with AMD. It has been known that at least some of the factors predisposing to the development of this disease are defined as modifiable (dietary habits, smoking, diabetes, cardiovascular disease), i.e. the ones the patient can change. This can be considered a failure not only on the part of the patients, but also health care workers, as according to Lawrenson and Evans [29] in the UK this type of information is provided only by $67.9 \%$ of the medical staff to patients diagnosed with AMD and by $53.6 \%$ to patients at risk of developing the disease. In my research, $61 \%$ of the respondents started taking vitamins and nutritional supplements after diagnosis. Similar data have been reported in other countries [30].

\section{Conclusions}

In conclusion, it should be noted that the vast majority of studies evaluating the effect of macular degeneration and its treatment on the prevalence of depressive disorders, anxiety, insomnia and life quality, have focused mainly on the loss of vision and deterioration of visual acuity. The results of this study indicate, however, that visual acuity alone does not provide an adequate basis for the assessment of these parameters. AMD may affect the eyes in many ways and may not only cause deterioration of visual acuity but also impair central vision, metamorphopsia, micropsia and macropsia. It can deteriorate contrast sensitivity and extend glare recovery time, which can significantly impair the quality of life, be a powerful stressogenic factor and in consequence lead to depression.

The results of my research show that patients with AMD are at risk of developing depression and therefore should be cared for by a multidisciplinary team, including an ophthalmologist, a family doctor, a psychiatrist and a psychologist.

\section{References:}

1. Bloom HG, Ahmed I, Alessi CA, Ancoli-Israel S, Buysse DJ, Kryger MH, et al. Evidence-based recommendations for the assessment and management of sleep disorders in older persons. J Am Geriatr Soc. 2009; 57: 761-789. https://doi.org/10.1111/j.1532-5415.2009.02220.x

2. Paĺsson SP, Ostling S, Skoog I. The incidence of first-onset depression in a population followed from the age of 70 to 85. Psychol Med. 2001; 31: 1159-1168. https://doi.org/10.1017/S0033291701004524

3. Turczyński J, Bilikiewicz A. Depresja u osób w podeszłym wieku. Psychiatria w Praktyce Ogólnolekarskiej. 2002; 2: 99-107 (in Polish).

4. Büchtemann D, Luppa M, Bramesfeld A, Riedel-Heller S. Incidence of late-life depression: a systematic review. J Affect Disord. 2012; 142: 172-179. https://doi.org/10.1016/j.jad.2012.05.010

5. World Health Organization. Global data on visual impairments [Internet]. Geneva:World Health Organization; 2010 [cited 2016 Jun 23].

Available from: http://www.iapb.org/sites/iapb.org/files/ GLOBALDATAFINALforweb.pdf

6. Ishii $\mathrm{K}$, Kabata T, Oshika T. The impact of cataract surgery on cognitive impairment and depressive mental status in elderly patients. Am J Ophthalmol. 2008; 146: 404-409. https://doi.org/10.1016/j.ajo.2008.05.014

7. Mabuchi F, Yoshimura K, Kashiwagi K, Yamagata Z, Kanba S, Iijima H, et al. Risk factors for anxiety and depression in patients with glaucoma. Br J Ophthalmol. 2012; 96: 821-825.

https://doi.org/10.1136/bjophthalmol-2011-300910 
8. Cruess A, Zlateva G, Xu X, Rochon S. Burden of illness of neovascular age-related macular degeneration in Canada. Can J Ophthalmol. 2007; 42: 836-843. https://doi.org/10.3129/i07-153

9. Voleti VB, Hubschman JP. Age-related eye disease. Maturitas. 2013; 75: 29-33. https://doi.org/10.1016/j.maturitas.2013.01.018

10. Kański J. Okulistyka kliniczna. Wrocław: Elsevier Urban \& Partner; 2009 (in Polish).

11. Campos Costa I, Nogueira Carvalho H, Fernandes L. Aging, circadian rhythms and depressive disorders: a review. Am J Neurodegener Dis. 2013; 2: 228-246.

12. Bhutto I, Lutty G. Understanding age-related macular degeneration (AMD): relationships between the photoreceptor/retinal pigment epithelium/Bruch's membrane/choriocapillaris complex. Mol Aspects Med. 2012; 33: 295-317. https://doi.org/10.1016/j.mam.2012.04.005

13. Soldatos CR, Dikeos DG, Paparrigopoulos TJ. Athens insomnia scale: validation of an instrument based on ICD-10 criteria. J Psychosom Res. 2000; 48: 555-560. https://doi.org/10.1016/S0022-3999(00)00095-7

14. Beck AT, Ward Ch, Mendelson M, Mock J, Erbaugh J. An inventory for measuring depression. Arch Gen Psychiatry. 1961; 4: 561-571. https://doi.org/10.1001/archpsyc.1961.01710120031004

15. Adeoti C, Akang EE. Disorders of the sleep-wake cycle in blindness. West Afr J Med. 2010; 29: 163-168.

16. Leger D, Guilleminault C, Defrance R, Domont A, Paillard M. Prevalence of sleep/wake disorders in persons with blindness. Clin Sci (Lond). 1999; 97: 193-199. https://doi.org/10.1042/CS19990004

17. Almeida OP, Pfaff JJ. Sleep complaints among older general practice patients: association with depression. Brit J Gen Pract. 2005; 55: 864-866.

18. Riemann D, Voderholzer U. Primary insomnia: a risk factor to develop depression? J Affect Disord. 2003; 76: 255-259. https://doi.org/10.1016/S0165-0327(02)00072-1

19. Brody BL, Gamst AC, Williams RA, Smith AR, Lau PW, Dolnak D, et al. Depression, visual acuity, comorbidity, and disability associated with age-related macular degeneration. Ophthalmology. 2001; 108: 1893-1900. https://doi.org/10.1016/S0161-6420(01)00754-0

20. Rovner BW, Casten RJ, Tasman WS. Effect of depression on vision function in age-related macular degeneration. Arch Ophthalmol. 2002; 120: 1041-1044. https://doi.org/10.1001/archopht.120.8.1041

21. Qian Y, Glaser T, Esterberg E, Acharya NR. Depression and visual functioning in patients with ocular inflammatory disease. Am J Ophthalmol. 2012; 153: 370-378. https://doi.org/10.1016/j.ajo.2011.06.028

22. Carney RM, Rich MW, Tevelde A, Saini J, Clark K, Jaffe AS. Major depressive disorder in coronary artery disease. Am J Cardiol. 1987; 60: 1273-1275. https://doi.org/10.1016/0002-9149(87)90607-2

23. Irwin MR. Depression and insomnia in cancer: prevalence, risk factors, and effects on cancer outcomes. Curr Psychiatry Rep. 2013; 15(11): 404. https://doi.org/10.1007/s11920-013-0404-1

24. Weterle K, Sołtysiak J. Objawy depresji i ich wykrywalność przez lekarzy podstawowej opieki zdrowotnej u pacjentów po 65. roku życia. Nowiny Lekarskie. 2006; 5: 433-437 (in Polish).

25. Kowalska J, Rymaszewska J, Szczepańska-Gieracha J. Occurrence of cognitive impairment and depressive symptoms among the elderly in a nursing home facility. Adv Clin Exp Med. 2013; 22: 111-117.

26. Chojnacka C. Zależność występowania objawów depresyjnych od obniżenia ostrości wzroku u chorych hospitalizowanych na oddziale okulistycznym. Psychiatria w Praktyce Ogólnolekarskiej. 2005; 1: 27-31 (in Polish).

27. Williams RA, Brody BL, Thomas RG, Kaplan RM, Brown SI. The psychosocial impact of macular degeneration. Arch Ophthalmol. 1988; 116: 514-520. https://doi.org/10.1001/archopht.116.4.514

28. Barcelos-Ferreira R, Lopes MA, Nakano EY, Steffens DC, Bottino CM. Clinical and sociodemographic factors in a sample of older subjects experiencing depressive symptoms. Int J Geriatr Psychiatry. 2012; 27: $924-930$. https://doi.org/10.1002/gps.2803

29. Lawrenson JG, Evans JR. Advice about diet and smoking for people with or at risk of age-related macular degeneration: a cross-sectional survey of eye care professionals in the UK. BMC Public Health. 2013; $13: 564$. https://doi.org/10.1186/1471-2458-13-564

30. Chang CW, Chu G, Hinz BJ, Greve MD. Current use of dietary supplementation in patients with age-related macular degeneration. Can J Ophthalmol. 2003; 38: 27-32. https://doi.org/10.1016/S0008-4182(03)80005-4 